\title{
Quantitative Review of Ecosystem Services and Disservices Studies in the Tropics
}

\section{Evariste Rutebuka ${ }^{1,2,3,6^{*}}$, Abel Olajide Olorunnisola ${ }^{1,2}$, Olalekan John Taiwo ${ }^{1,4}$, Francis Mwaru ${ }^{3}$, Ernest Frimpong Asamoah ${ }^{5}$, Emmanuel Rukundo ${ }^{5}$}

\author{
${ }^{1}$ Department of Environment Management, Institute of Life and Earth Science, Pan-African University (PAULESI), \\ Ibadan, Nigeria \\ ${ }^{2}$ Department of Agricultural and Environmental Engineering, Faculty of Technology, Ibadan University, Ibadan, Nigeria \\ ${ }^{3}$ Department of Geography \& Environmental Studies, University of Nairobi, Nairobi \\ ${ }^{4}$ Department of Geography, University of Ibadan, Ibadan, Nigeria \\ ${ }^{5}$ Department of Environment Sciences, Faculty of Science and Engineering, Macquarie University, North Ryde, Sydney, Australia \\ ${ }^{6}$ State Key Laboratory of Water Environment Simulation, School of Environment, Beijing Normal University, Beijing, China \\ Email: *ruteva07@gmail.com
}

How to cite this paper: Rutebuka, E., Olorunnisola, A.O., Taiwo, O.J., Mwaru, F., Asamoah, E.F. and Rukundo, E. (2019) Quantitative Review of Ecosystem Services and Disservices Studies in the Tropics. Open Journal of Ecology, 9, 85-106.

https://doi.org/10.4236/oje.2019.94008

Received: September 20, 2018

Accepted: April 26, 2019

Published: April 29, 2019

Copyright $\odot 2019$ by author(s) and Scientific Research Publishing Inc. This work is licensed under the Creative Commons Attribution International License (CC BY 4.0).

http://creativecommons.org/licenses/by/4.0/

(c) (i) Open Access

\begin{abstract}
The tropics host about $80 \%$ of the planet's terrestrial species and over $95 \%$ of its corals. A well-known tropical forest ecosystem to provide significant global regulating services has declined at a rate of $5.5 \mathrm{M}$ ha per year from 1990-2015, while another region noted an increase per year. There is evidence that tropical region ecosystem services and disservices are the least studied in the world. This study quantified peer-review papers in the tropics, then explored the neglected ecosystem type, service category, assessment mode, applied techniques and choice dependence between ecosystem type, service category, assessment mode and applied techniques. The Google Scholar and Web of Science database were used to collect all ES \& ED studies available online from 1960 to December 2017. This review covered 102 countries with 578 articles. The study showed dramatic articles increase in the last three years as more than $50 \%$ of articles were published after the year of 2014 . The top countries in high articles were Mexico $(n=53)$, India $(n=43)$, and Brazil $(\mathrm{n}=35)$. The ES \& ED assessment tools/techniques are barely applied in tropics as only social based techniques such as interviews and questionnaire take over $45 \%$, while biophysical tools like remote sensing and GIS appeared only in $20 \%$, InVEST only in $3 \%$ while the rest tools are less than $1 \%$ even none such as ARIES model. Urban and marine ecosystem types, disservices category and trade-off assessment mode were the least studied. The review concluded that policy analysis ES \& ED studies do not reflect the trade-offs and synergy analysis between different services which hinder the develop-
\end{abstract}


ment of pragmatic policy and decisions toward ES sustainable management in the tropics. The rampant urbanization in the tropics is subjected to destroy existing ES. Thus, this review highly suggested a high concern of urbanization ecosystem. This study also calls for great academic research to give attention to the tropical rainforest region as most African countries to host such forest have not even a single article on ES \& ED.

\section{Keywords}

Ecosystem Services, Disservices, Tropics, Country-Basis, Choice Dependence

\section{Introduction}

The world is divided into different regions based not only on the economic development index or continental boundary, but based on climatic patterns, which influence the earth ecosystem distribution patterns. With the climatic segregation in view, the tropics provide ecosystem services in enormous quantities and qualities. For instance, as the most diverse region of the earth, the tropics host about $80 \%$ of the planet's terrestrial species and over $95 \%$ of corals and mangroves [1] [2]. Moreover, the tropical rainforest sequesters carbon and has been considered as the lung of the world [3].

Regardless of its benefits to the wellbeing of the entire planet, an estimated $35 \%$ of its hosted species are threatened; at least 35\% of mangrove forest area was lost worldwide during the 1980s and 1990s alone; about $47 \%$ of its coral reef is at high risk. The primary forest is being lost at $0.5 \%$ ( $>4$ million hectares) per annum and the tropical forest area declined at a rate of $5.5 \mathrm{M}$ ha per year from 1990 to 2015 [1] [2] [4] [5] [6].

The social, demographic and economic facts are keys influencing the environmental degradation; the tropical regions are developing countries dominated except for Australia and Singapore [7]. Around 40\% of the world's population lives in the tropics [1]. At current rates of population growth, by 2050 more than half of the world's people will live in tropical regions with the most significant population growth in Africa [1].

Over the past 30 years, economic growth in the tropics has outperformed the rest of the world by almost $20 \%$ which resulted in high natural resources use and overexploitation. Despite this ecosystem degradation in the tropics, there is a restoration or ecosystem recovery in some regions as from 1990 to 2015, the temperate forest area expanded at a rate of $2.2 \mathrm{M}$ ha per year, forest area has also expanded in Europe, North America, but declined in Central America, South America, South and Southeast Asia and all three sub-regions of Africa [6].

Despite these facts about the tropics, there is evidence that tropical region ecosystem services and disservices are the least studied in the world. For instance, almost $60 \%$ of all ES \& ED were taken in Europe and North America [8].

Therefore, the overall objectives of this review are 1) to analyse trend of 
ES\&ED studies and its geographic distribution in the tropics; 2) to analyse ES \&ED studies based on ecosystem type, services category, mode of assessment, and applied tool/techniques 3) to analyse the choice dependence for selecting mode of assessment, service category or choose of techniques in the study.

This review aimed at contributing to the scientific understanding of ecosystem services in the tropics then identifying the neglected ES \& ED category, ecosystem type, alienated sub-region, country for paving a new way for further studies.

\section{Material and Methods}

Geographically, the study encompassed the tropical regions hereafter known as tropics. It lies between at 23.5 degrees north of the Tropic of Cancer and the Tropic of Capricorn at 23.5 degrees south of the equator. Based on the defined latitude ranges, some countries were straddling to tropical regions. In case of straddling, a country with less than a quarter of total country size inside the defined boundaries was deliberately taken out such as China, Qatar, and others.

A broad literature review of peer review papers (known as articles in this review) and non-peer-review papers (e.g. academic theses, organization technical reports, working papers, conference proceedings, books, and book sections) available online from 1960 until 2017 were consulted to describe the state of ES \&ED in tropics, then only the peer review papers (articles) were further analyzed. Only studies published in English or French were considered.

Since the term "ecosystem services" has evolved and used differently by different authors, the online terms and Boolean operators were carefully selected. For instance, the ecosystem services concept emerged in the 1970s as "environmental services" by Wilson and Matthews in 1970 and was re-named "ecosystem services" in the mid-1980s [9], Schumacher in 1973 used the concept of natural capital and shortly after several authors started referring to "ecosystem (or ecological, or environmental, or nature's) services" [10]. The term Natural Capital (NC), which was developed by a group of environmental economists and ecological economists such as Robert Costanza and Rudolf de Groot was also considered [11] [12]. In summary, the following terms or key word of ES\&ED available only in paper title and in keywords with Boolean operators were used as themes in Google Scholar and Web of Science search engine database to identify studies suitable for inclusion. 1) ecosystem AND service(s), OR disservice(s); 2) environmental service(s); 3) payment AND ES or ED; 4) Payment for Ecosystem Services (PES), 5) natural AND capital; 6) ecological AND service(s) or disservice(s); 7) Ecosystem AND function(s); 8) service(s) AND écosystémique(s); 9) PSE (Payement pour les services écosystémique(s)); 10) service(s) AND écologique(s); 11) service(s) AND environnementale(s) OR environnementaux; 12) Resource(s) AND naturelle(s); 13) Capital AND Naturel(s). These search terms and Boolean operators were followed by the name of each country and country nationality in English or French such as Kenya and Kenyan, Kényan(e). Africa, Asia, Latin America, South America, and Caribbean terms were added as coun- 
tries to include studies carried at regional scales.

All paper resulted in search were imported into Mendeley (Mendeley Ltd.; https://www.mendeley.com/) for paper title, authors, year of publication and paper type accuracy assessment and for further reference purpose. Duplicated papers were removed, and then the final checked list was transferred into $\mathrm{Mi}$ crosoft Excel for descriptive analysis. Lastly, review paper such as country review of ecosystem services, sub-region ecosystem review [13] [14] was excluded from analysis. The articles were organised in table with their title, publication year, assessed ecosystem category, mode of assessment, applied techniques, numbers of assessed services and disservices, assessed services and disservices names. The voyant tool (https://voyant-tools.org/), an open-source, web-based application for performing text analysis which supports scholarly reading and interpretation of texts or corpus was then applied to investigate the frequencies services and disservices such as erosion control, climate regulations, carbon sequestration, pollination, recreation, crop-raiding, allergenic pollen, disease vectors, decreased aesthetics, fear of crime, safety hazards, and others) [15] [16] [17].

Ecosystem services and disservices are assessed by using many tools/techniques [18] [19] [20]. In most cases, methods are different from tool or technique used to gather and analyze data. For example biophysical modeling method uses remote sensing or GIS as tools to analyse satellites images; socio-cultural methods mostly involves stakeholder (interview and questionnaires) techniques to gather data; monetary valuation method uses contingent valuation technique [20] [21]. Many articles did not clearly describe its method such as in [22] [23] but, most of them showed either used techniques to collect data or applied tools to analyze data. Therefore, the present study assessed tools and techniques than methods.

Further, the analysis of variance (ANOVA) was applied to explore if there is any dependence between choice of tool/techniques (interview \& questionnaire, remote sensing, and GIS, contingent valuation, integrated valuation of ecosystem services and trade-offs (InVEST) and others), and mode of assessment such as (quantification, qualification, valuation and others) or choice of target ecosystem service category (such as provisional, regulating and others).

\section{Results}

\subsection{Geographical Distribution, Trends of ES Studies}

The study covered 50 countries from Africa, six from Australia and Pacific Islands, 29 from Central, Latin America and the Caribbean (C.L.A.C), and 17 from Asia (Figure 1). Table 1 provides the results of the articles and non-peer-reviewed paper resulted from Mendeley referencing software and categorised into study regions. Overall, 1061 papers were recorded, which included 578 articles, 128 conference proceedings, 151 academic theses (Master's or Ph.D. programs), 104 working papers, 62 reports, and 38 books and book sections. The average article publication per country was 5.8 . Most of papers $(n=387,36 \%)$ were recorded in Africa whereas the least was inter-continental scale 11 paper representing $1 \%$ of 


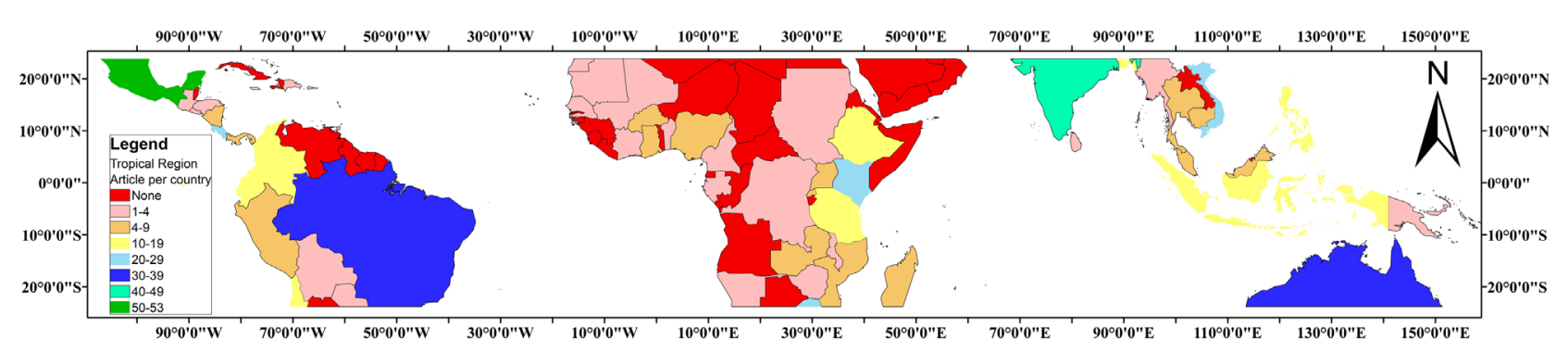

Figure 1. ES \& ED: Distribution of articles in tropics at a country level until 2017.

Table 1. Geographic distribution of ES and ED studies

\begin{tabular}{|c|c|c|c|c|c|c|c|c|c|c|c|c|c|c|c|c|}
\hline \multirow{2}{*}{ Region } & \multicolumn{2}{|c|}{ A } & \multicolumn{2}{|c|}{ B } & \multicolumn{2}{|c|}{$\mathrm{C}$} & \multicolumn{2}{|c|}{ MT } & \multicolumn{2}{|c|}{ PT } & \multicolumn{2}{|c|}{$\mathbf{R}$} & \multicolumn{2}{|c|}{ WP } & \multicolumn{2}{|c|}{ Total } \\
\hline & $\mathrm{n}$ & $\%$ & $\mathrm{n}$ & $\%$ & $\mathbf{n}$ & $\%$ & $\mathbf{n}$ & $\%$ & $\mathbf{n}$ & $\%$ & $\mathrm{n}$ & $\%$ & $\mathrm{n}$ & $\%$ & $\mathbf{n}$ & $\%$ \\
\hline C.L.A.C & 218 & 38 & 11 & 29 & 29 & 22 & 39 & 34 & 19 & 44 & 17 & 27 & 35 & 34 & 369 & 35 \\
\hline Africa & 188 & 33 & 15 & 40 & 53 & 41 & 62 & 54 & 9 & 25 & 26 & 41 & 33 & 32 & 385 & 36 \\
\hline Asia & 139 & 24 & 10 & 26 & 30 & 23 & 12 & 10 & 7 & 20 & 13 & 21 & 34 & 33 & 245 & 23 \\
\hline Australia & 29 & 5 & 1 & 2 & 15 & 18 & 2 & 2 & 1 & 3 & 3 & 5 & & & 51 & 5 \\
\hline Inter-continent & 4 & 0.6 & 1 & 2 & 1 & 0 & - & - & & & 3 & 5 & 2 & 2 & 11 & 1 \\
\hline Total & 578 & & 38 & & 128 & & 115 & & 36 & & 62 & & 104 & & 1061 & \\
\hline
\end{tabular}

A. Article, B. Book \& Book section, C. Conference proceeding, MT. Master Thesis, PT. Ph.D. Thesis, R. Report, WP. Working Paper.

total papers. The majority of the articles $(\mathrm{n}=218,38 \%)$ were published in C.L.A.C compared to Africa $(\mathrm{n}=188,32 \%)$ (Table 1).

All reviewed papers were in English except five papers conducted in Senegal, Burkina Faso Kenya [24]-[28].

Regarding country specificity, Mexico had the highest number of article ( $n=$ $53,24 \%$ of C.L.A.C) followed by India (43,31\% of Asia), Brazil $(35,16 \%$ of C.L.A.C). Approximately, $45 \%$ of all assessed countries are still categorised as none article publication, for example, Algeria, Niger, Saudi Arabia, Cuba and Somalia and others (Figure 1).

With regard to publication age, there were three oldest papers published in 2000 from Brazil, Mexico and El Salvador [29] [30] [31]. The trend analysis showed that the majority of articles were published in the recent three years, from 2015 to 2017, which represents half of articles (Figure 2).

Apart from articles, the oldest publication was a working paper published in 1992 [32] while the oldest thesis was in 2002 [33] and more than $80 \%$ of non-peer review papers were published after 2009 (Figure 3).

\subsection{Studies Based on Ecosystem Types}

All articles were categorized into seven ecosystem types namely agro-ecosystems (AE), forest ecosystems (FE), wetland ecosystems (WE), urban ecosystems (UE), marine ecosystems (MrE), mixed ecosystem (ME) and non-described ecosystems (NDE). 


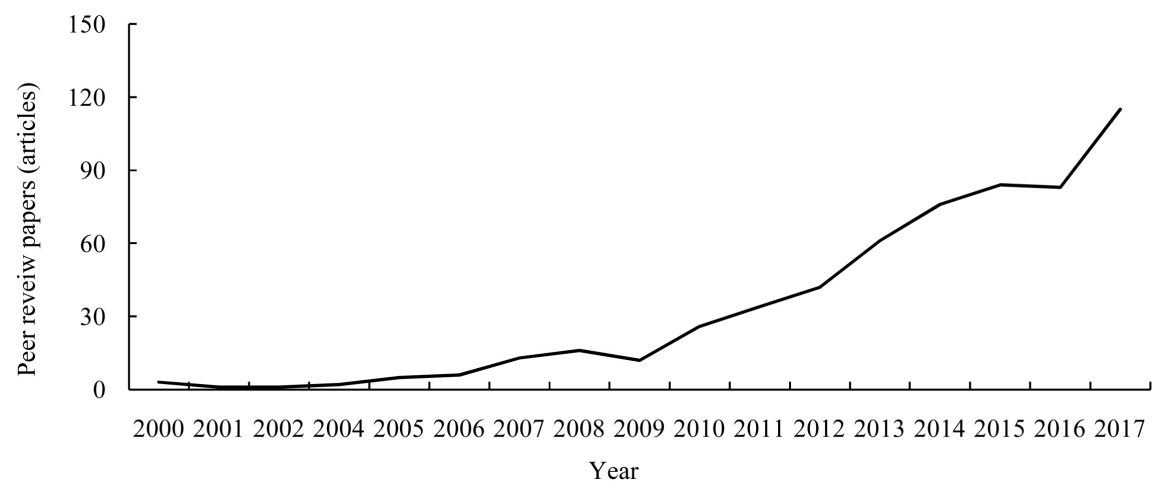

Figure 2. ES \& ED's article trending.

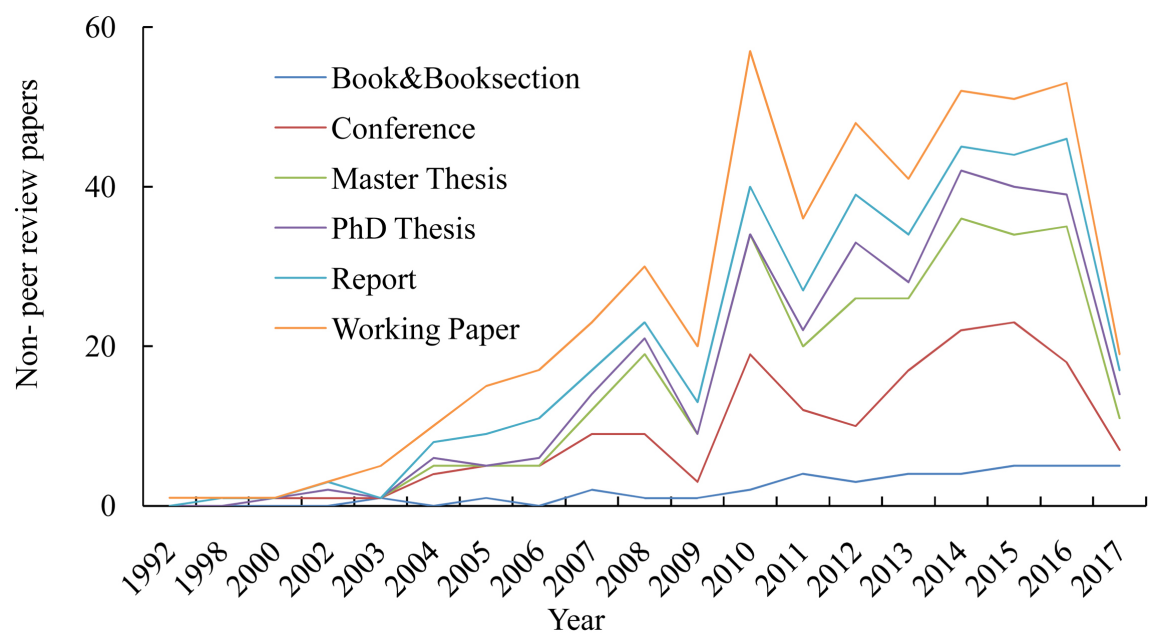

Figure 3. ES \& ED non-peer review publication trending.

About 33\% ( $n=188)$ of articles reported agroecosystem among them 115 uniquely studied AE such as coffee cultivation in Latin America [34] while 73 were a mixture of ecosystem type such as $\mathrm{AE}$ and $\mathrm{FE}$ such as in ecosystem services of native trees: experiences from two traditional agroforestry systems in Karnataka, Southern India [35]. Here are some examples of articles combined AE and other ecosystem types like in mountain ecosystem assessment based on ecosystem services and human activities combined AE\&WE [36], AE\&UE in environment diversity and ecosystem services in Amazonian home-gardens of Ecuador [37]. Among all AE studies, only one covered AE \& MrE when studying spatial and temporal dynamics of multidimensional well-being, livelihoods, and ecosystem services in coastal Bangladesh [38] (Figure 4).

Forest ecosystem related articles were $25 \%(n=144)$ of total articles in which only 95 solely explored FE. The wetland ecosystem related studies were 16\% ( $n=$ 96) of articles and only 56 studies were uniquely WE. The mixed ecosystem (ME) in which the study covered more than two ecosystem types were $14 \%$. The $16 \%$ of the studies did not describe their ecosystem type and were considered as non-described ecosystem (NDE) such as understanding the governance of the payment for environmental services program in Costa Rica [39]. Urban ecosystem 


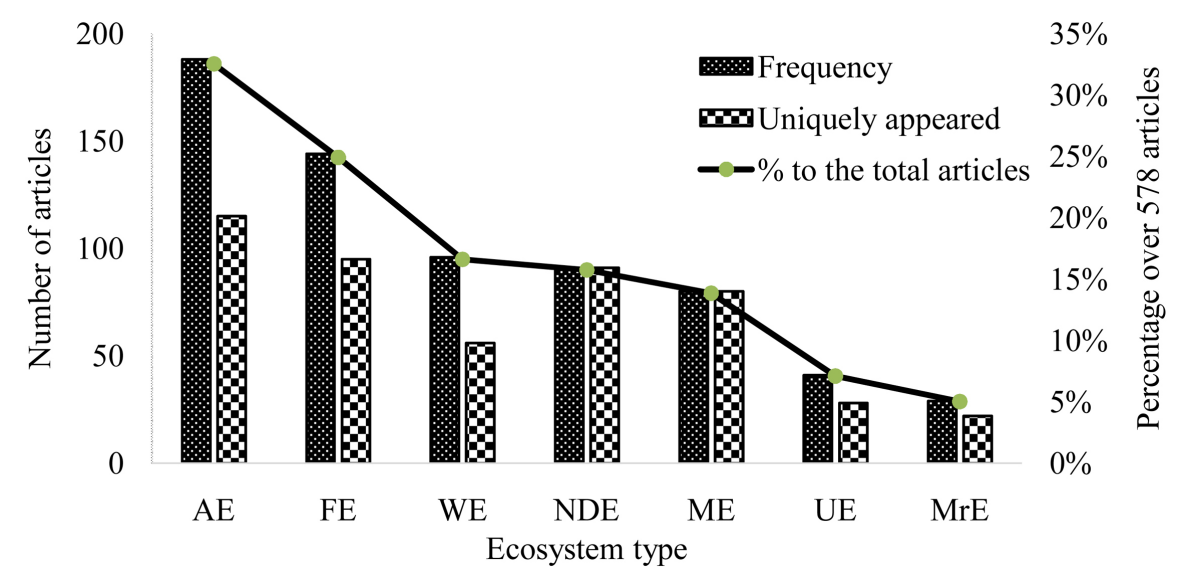

Figure 4. ES \& ED studies distribution based on ecosystem type.

(UE) related studies were 41 articles almost $7 \%$ of the total articles.

The present study found 11 articles on UE in C.L.A.C such in Brazil, Chile, Ecuador [37] [40] [41]. The least concerned was marine ecosystem (MrE) with 29 articles or 5\% of articles. Detected MrE studies in this paper is the pioneer of coastal and marine ecosystem services in the tropics as the recent review studies showed that none marine ecosystem studies were conducted in neither Africa nor C.L.A.C [42]. These MrE studies presently are in Africa [43] [44] [45], Mauritania and Martinique [46] [47] but more than a half of MrE studies were published in South America and Mexico.

\subsection{Studies Distribution Based on Ecosystem Service Categories}

Ecosystem services were categorised differently by diverse framework which include the Common International Classification of Ecosystem Services (CICES), the Millennium Assessment Framework (MA), The Economics of Ecosystems and Biodiversity (TEEB), Intergovernmental Science-Policy Platform on Biodiversity and Ecosystem Services (IPBES) [48] [49] [50] [51] [52]. This study used the MA ecosystem services categories [49] plus ecosystem disservices category firstly introduced by Lyytimäki et al. [53].

The total of 106 articles ( $18 \%$ of all articles) studied the combination of provisional, regulation, supporting and cultural services.

Two hundred and thirty two articles representing $40 \%$ of all articles did not describe ecosystem service category targeted in their study (G) such as ecosystem services to enhance coastal resilience in Mexico; the gap between the perceptions of decision-makers and academics; Payment of environmental services in Costa Rica; evaluating impact and possibilities; the impact of payments for environmental services on communal lands; an analysis of the factors driving household land-use behavior in Ecuador; How to finance biodiversity conservation policies in a developing country through ecosystem Services, case of Mozambique [54] [55] [56] [57] (Figure 5).

Provisional services were the most discussed service with level of $48 \%$ ( $n=279$ over 578), regulating services in $41 \%$ (238), supporting in $28 \%$ (164), cultural 


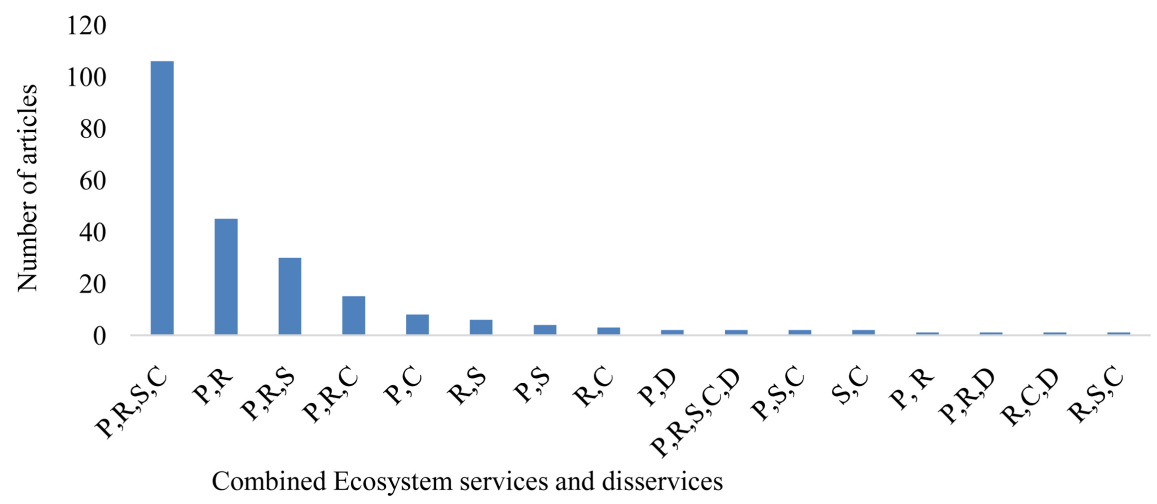

Figure 5. Ecosystem services and disservices Combined.

services in $27 \%$ (156), and disservices only appeared in 1\% (6) (Figure 6).

The voyant text analysis tool (http://voyant-tools.org) provided a schematic view of the 239 different services were studied (Figure 5). The ten most expressed services were food provision assessed in 101 articles, erosion control (64), biodiversity (62), recreational (58), climate regulation (51), firewood (48), carbon sequestration, medicine provision, water supply, habitat and medicine in 44 articles. The least studied services include regulating human disease only mentioned in the study of Mhango et al. [58], cyclone protection service in Madagascar only Zaehringer et al. [59]. The number of articles with disservices concern has increased in the tropics as in published 578 articles, disservice(s) word appeared in 34 articles with 317 instances.

In the first six papers in which most disservices instances were found, four papers were from Africa and one from India and Brazil. Three articles were distributed across Ethiopia like desegregated ecosystem services and disservices in the cultural landscapes; balancing ecosystem services and disservices; long-term changes in soil-based ecological services [60] [61] [62]; local knowledge regarding ecosystem services and disservices from invasive alien plants in the arid Kalahari, South Africa, that captures all ecosystem categories and disservices [63]; In Brazil, Sánchez et al. (2017) valued Alternative biodiesel feedstock systems in the Semi-arid region of Brazil: Implications for ecosystem services. The last was in India valuing forest ecosystem services and disservices [64].

\subsection{The Assessment Mode for Ecosystem Services and Disservices}

The study identified six modes of assessment, which included mapping (M), quantification $(\mathrm{Q})$, qualification $(\mathrm{Ql})$, economic valuation $(\mathrm{EV})$, policy analysis (PA) and trade-offs (ToF). Policy analysis was the most applied mode as it appeared in $44 \%$ of all articles $(n=256)$ followed by quantification $31 \%(n=181)$ and the least applied mode was trade-offs analysis with $12 \%(n=67)$. More than a half articles used single mode $60 \%(n=345)$ in which policy analysis as uniquely applied in whole article was the leading with $58 \%$ then qualification with $30 \%$ of 345 articles such as in [65] [66] [67]. The rest modes were almost mixed with other as only nine articles uniquely used mapping and none article used 


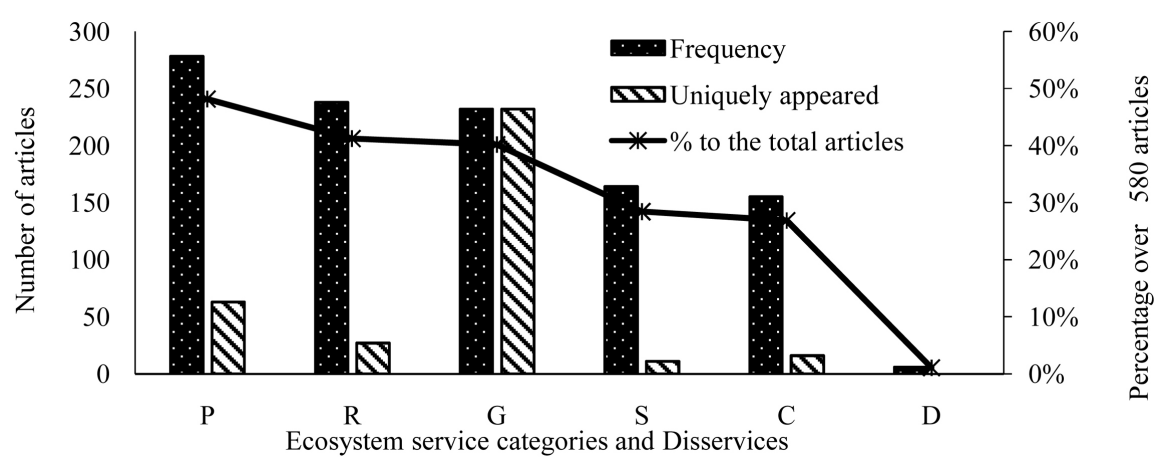

Figure 6. ES \& ED studies distribution based on services categories.

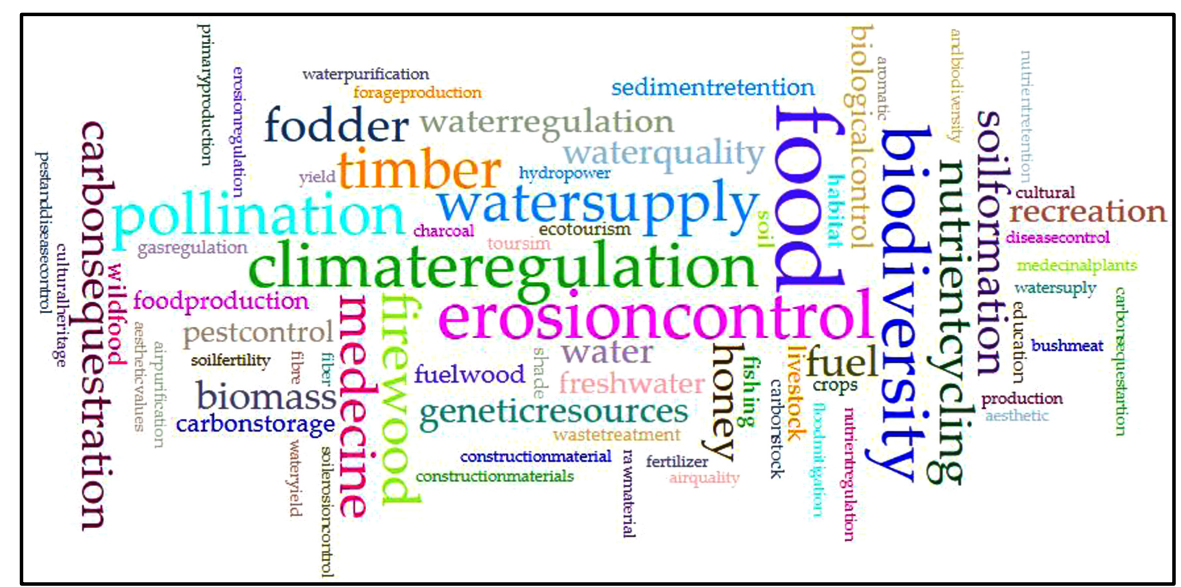

Figure 7. The most targeted services in all ES and ED categories.

uniquely trade-offs (Figure 8).

Articles with a combined mode of assessment were $40 \%(n=233)$ with 49 combinations in which the most represented combination was quantification and qualification $(n=23)$ while the 29 combinations were represented by less than two articles. For example only one article represented the combined of EV, Q, Ql, and ToF [68], EV, M, PA and ToF [69] (Figure 9).

\subsection{Ecosystem Services and Disservices Assessment Tool and Techniques}

The present study identified more than ten tool/techniques aggregated into Interview \& Questionnaire (IQ), Review, Remote sensing and GIS (RS \& GIS), Contingent Valuation (CV) Integrated Valuation of Ecosystem Services and Trade-offs (InVEST), field survey, Soil and Water Assessment Tool (SWAT), Choice Experiment (CE), Multi-Criteria Analysis (MCA) and Non-monetary Valuation Scheme (NMVS). The Interview \& Questionnaire (IQ) technique was the most applied with $44 \%(n=262)$ articles. The field survey technique involves sampling techniques such transect, biomass quantifying using field measurement, laboratory analysis, such as soil was in the second position with $29 \%$ ( $n=$ 167) of all articles [70] [71] [72]. The reviewing technique used the historical data (secondary data) then combine with current data to complete intended 


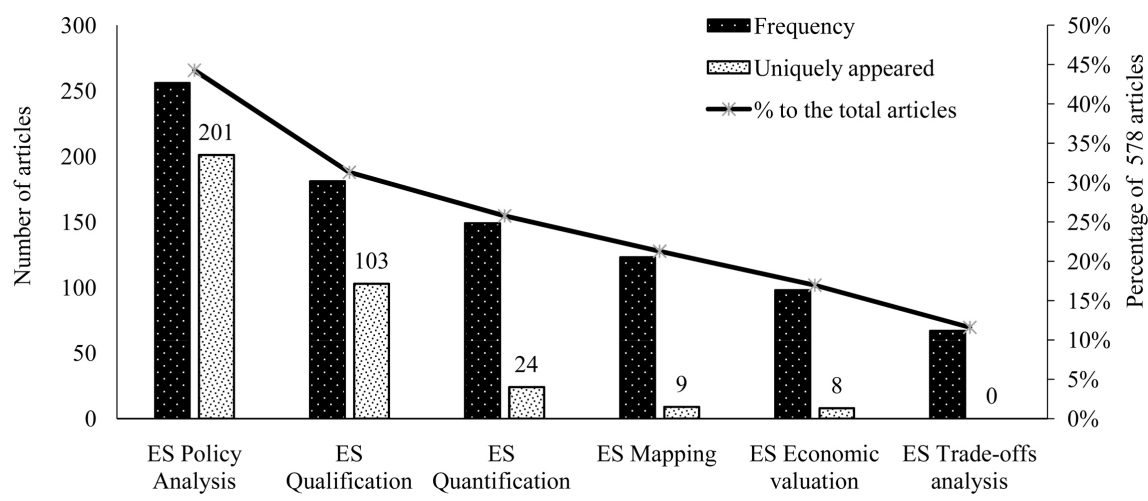

Figure 8. Mode of assessment: Ecosystem services and disservices.

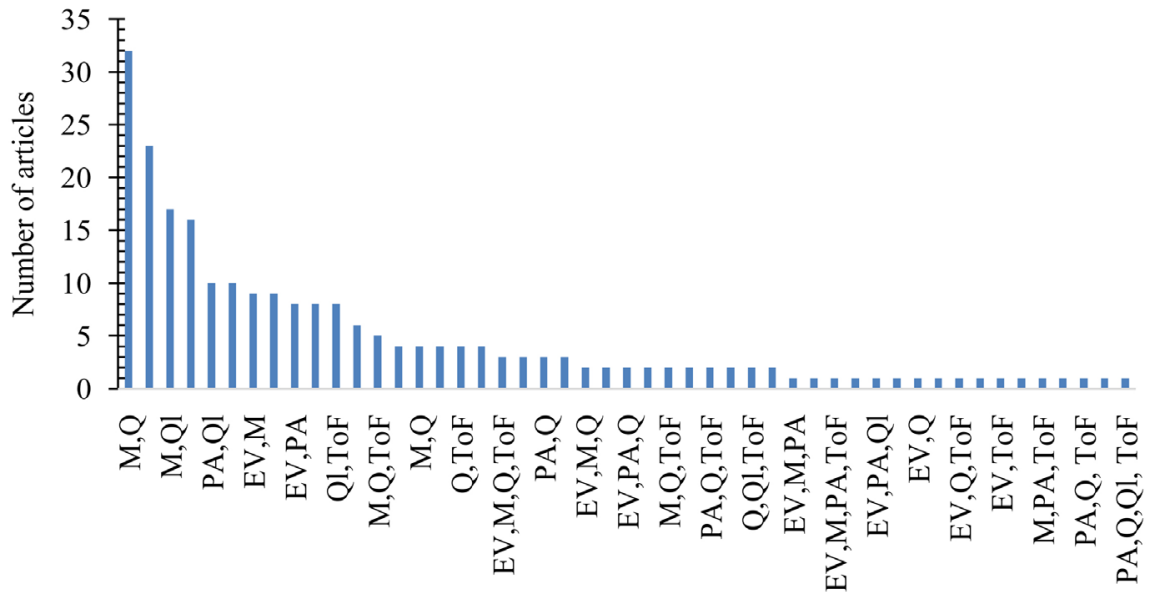

Combined mode of assessment

Figure 9. Combined mode of assessment: Ecosystem services and disservices.

study appeared in $27 \%(n=158)$ such as in [73] [74] [75]. Remote sensing and GIS were applied in almost $20 \%(n=116)$, Contingent Valuation (CV) appeared in $12 \%(n=69)$, InVEST model $3 \%(n=17)$ while each of CE, SWAT and NMVS and others were represented $1 \%$ or less than that of the total articles.

\subsection{Choice Dependence between Ecosystem Type, Service Category, Assessment Mode and Applied Techniques}

The present review showed over $70 \%$ of 256 articles of policy analysis assessment mode did not describe the ecosystem services categories while other modes such as quantification, trade-offs analysis modes addressed carefully the service category on focus. For instance, $61 \%$ of articles with quantification as mode of assessment addressed provisional services. The trade-offs analysis mode was the least applied mode and has focused mostly on provisional services at $69 \%$ of its articles.

The distribution of articles based on applied tools/techniques, 262 articles applied Interview and Questionnaire. Some articles used I\&Q in more than one mode of assessment as 135 articles were PA, 137 qualifications, 58 quantification, 56 mapping, 61 economic valuation and 44 Trade-offs (Figure 10). 


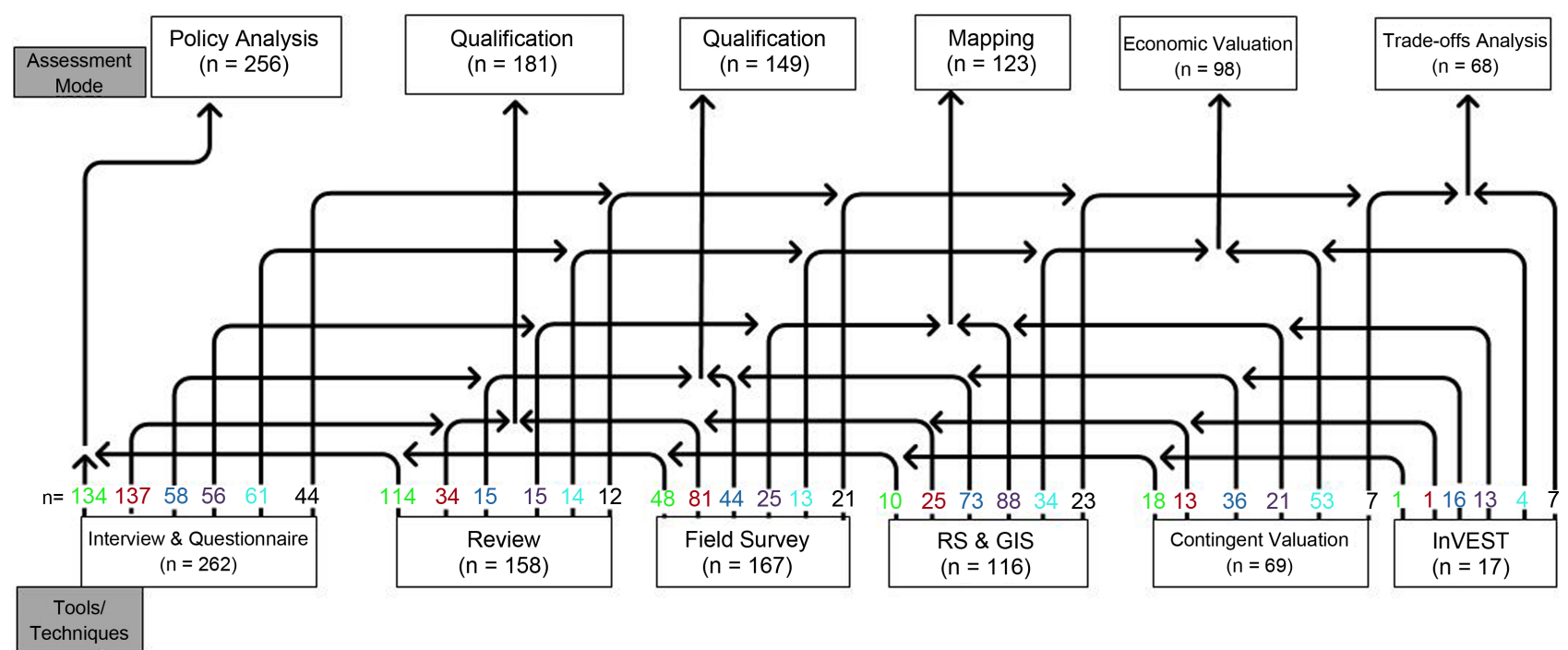

Figure 10. Dependence distribution between tools/techniques and assessment mode for ES \& ED.

The Welch robust test of one-way ANOVA at a confidence interval of $95 \%$ showed that the choice of techniques does not depend on mode of assessment with p-value of 0.379 . Also, the same test showed none dependence between ecosystem type and selection of services categories with $\mathrm{p}$-value $=0.451$. Contrarily, the assessment mode was significantly associated to the ecosystem service type $(\mathrm{p}$-value $=0.001)$ with post-hoc analysis which showed that this significance was due to disservices category.

\section{Discussions}

\subsection{ES \& ED Studies Distribution}

The first kind of ES study in the tropic region dates back in 1992 and was not explicitly focusing on ecosystem service where report used natural capital concept than ecosystem services [32]. Only three articles in the tropics were published before the launch of the Millennium Ecosystem Assessment in 2005, including countries such as Mexico, Brazil and El-Salvador [29] [30] [49] [31]. This reaffirms the impacts of the MEA on ecosystem service awareness and their studies. The article on ecosystem services was first recorded in C.L.A.C in 2000, Asia 2008, Australia in 2005, Africa in 2007 and Asia in 2008. Until 2017, the whole tropical countries were not yet covered by ecosystem service studies as half of African countries, 10 to 29 C.L.A.C countries and 5 to 17 in Asia have not yet any article. This study acknowledges the cumulative impact of the contribution of MA, TEEB and IPBES framework [49] [50] [52].

Additionally, a good number of African countries moved from none article list and get at least one article such as Rwanda, Democratic Republic of Congo (DRC), Zimbabwe and others while Kenya has taken over South Africa as the first countries in Africa with high articles when compared to a review of 2014 [14]. 
The geographical disparities in ES and ED studies may be attributable to the environmental awareness propounded by Rachel Carson in the 1960s throughout the American regions before reaching furthest geographic locations [76]. Mexico witnessed the emergence of an environmental movement which grew in size and strength and that, by the mid-1990s, had gained national visibility. More importantly, during a series of environmental reforms implemented during the 1990s, Mexican environmentalists were successful in influencing national environmental policy and achieved a series of significant policy triumphs [78]. The environmental movement is also the primary cause of environmental literacy and environmental policy development which results in high research output on the matter of environmental related studies. This is typical for the first two top ranked African countries tropics Kenya (4th) and South Africa (5th). These two first African countries experienced a pronounced environmental movement than other African countries such as the Green Belt environmental movement started in 1977 in Kenya [79] [80] [81]. The environmental literacy factor of ES \& ED publication is an evidence as other reviewing studies found that more ES \& ED studies are more available in Europe and North America where environmental literacy is high [8] [82] [83] [84].

The countries with no ES \& ED article were concentrated in central Africa region (Burundi, Chad, Central Africa Republic) despite hosting the most substantial part of tropical rainforest in Africa [85]. On this no article lists are the North African countries (e.g. Algeria, Niger, Libya) and all West Africa except Ghana and Nigeria, who are French speakers which correlate to this study results in which only five articles were published in French. Thus, a critical gap of ecosystem services related studies is suspected in African French-speaking countries than English speaking countries. English as a requirement for publication limit the contributions from countries where English is not an academic language of instruction as English is also the most dominant academic language worldwide [86]. All reviewed articles were in English exceptive conducted in West Africa (Senegal and Burkina Faso) and one from Kenya with the author from France [24] [25] [26] [27] [28] and were published in three journals "[VertigO] La revue électroniqueen sciences de l'environnement; International Journal of Biological and Chemical Sciences, L'Espacegéographique". African countries with a high number of articles are English speaking countries such as Kenya, South Africa, Tanzania, Ethiopia, and Nigeria. Thus, English seems to be a publication hindrance as most of the ecosystem-related studies are published in English. The Asiatic sub-tropical region is ranked the best region to have an even distribution of publications as more countries were more than five publications, and only Lao was the only mainland country with none article. This sub-region, English is the first foreign language a long time ago such as Singapore, Malaysia, Philippines, and Brunei or second language. Recently English become also the first foreign language in Cambodia, Thailand, and Vietnam, which have boosted their international integration and academic writing in English [87]. 


\subsection{Ecosystem Type, Services, Disservices and Trade-Offs in Tropical Regions}

The study remarked the lack of interest in urban ecosystem while previous studies have stated that urbanization can easily lead to ecosystem trade-off and exacerbate degradation and disrupt connectivity of interconnected ecosystem providing unit [88] [89] [90] [91]. This low number of UE in tropical region reflects the result of Haase et al. [83] when reviewing global urban ecosystem as their study stated that most of the studies were in developed countries (Europe and North America) and China. This study showed a slight increase of UE articles as in Africa as only South Africa was the only one country with urban ecosystem service article, but now Tanzania, Nigeria, and Ethiopia have at least one [92] [93] [94]. In this review, two cases typically analysed the conversion land-type to urban land in the aspect of trade-offs such as agricultural land to urban in Santiago-ValparaôÂso Chile and economic value decline due to urbanisation in Chiang Rai Province, Thailand [41] [95]. Urbanisation and ecosystem services trade-off analysis is still uncovered in the tropics which implies that land conversion to urban is being conducted without ES trade-offs and synergy analysis. This is apparently leading to the reduction or losses of other ecosystem services [96] [97]. This study witnessed an improvement of $\mathrm{MrE}$ as in the past ES review study, MrE was barely considered [14] [83] [98] [99].

The ES trade-off analysis is a critical gap in analysis aspect as urbanization and urban growth trend showed that $90 \%$ of 2030 projected changes are expected to take place in the tropics, such as Africa [100] and also the world's 20 fastest-growing urban regions are in Africa and in Asia [101]. The tropics are more vulnerable to urbanisation effects than others because not only of negative urbanisation effects but also it's limited resources to cope and to address environmental degradation impacts resulted from ecosystem degradation [14] [102] [103].

In 2008, Lyytimäki et al. described negatives function and services from UE, for example, aesthetic issues, safety and security and health issues, economic issues, mobility issues. In 2010 ecosystem disservices got high attention through global mapping of ecosystem disservices as an unspoken reality that nature sometimes kills us [104]. Since then, some ecosystem framework has been designed which account services and disservices [105]. This correlates with the present study results as ecosystem disservices have gained attention with six articles while in all past review studies disservices seem to be side-lined. Shackleton et al. [106] argued that overlooking ecosystem disservices is problematic for following reasons: 1) they are real and environmental management systems should take them into account, 2) ignoring them will imply that the positive links between ecosystem services, biodiversity and human well-being will be constrained or suboptimal, 3) it will prevent recognition of actions that reduce ecosystem disservices to improve well-being and 4) only looking at ecosystem services and ways to increase them may fail to consider the potential simultaneous increase in 
magnitude of disservices. Vaz et al. [107] suggested that accounting for disservices could help in pinpointing management alternatives that minimise them. Despite progress discussion of ecosystem disservices in developed countries such as Europe and North America, ED concept is not yet either integrated into academia in tropics as only six articles now prompted to clearly discuss disservices in whole tropics [61] [62] [63] [64].

\section{The Caveat of This Review Paper}

The present study might have left out some existing studies related to ecosystem services as our search only discovered the papers with the key word of ES\&ED available only in paper title and keywords. In addition, papers published not in English or in French were not covered in this review paper and non-online papers were not covered as the possibility to access them was not possible for us.

\section{Conclusions}

Since the publication of Millennium Assessment in 2005 and other frameworks (such as TEEB, IPBES) developed later, ecosystem services have gained much attention and have been used to drive various policies. Regardless of the increment in publications, ecosystem services, and disservices are barely studied in central African region which host a larger proportion of African rainforest.

The environmental literacy level influences distribution of studies in tropic as most countries with the environmental movement of 1960s, and late 90s has a higher number of publications on ecosystem services such as South Africa, Kenya, and Mexico.

French-speaking countries have academic writing barrier as most journals publish articles in English and study revealed that most studies are conducted in the countries where English is one of national official language and English is an academic language of instruction. On the side of Asia and publication language barrier, most Asiatic countries have adopted English as the first foreigner language, which has fastened their publication in recent years.

Ecosystem services and disservices in the tropics are mostly focusing on policy analysis, profoundly discussing payment of ecosystem services than quantifying, mapping and valuation. This policy analysis aspect is not helping policy and decision makers as a critical aspect of ES\&ED trade-offs and synergy analysis is left out in most undertaken studies.

Despite rampant urbanisation and urban growth in the tropics than the rest of the world, the urban ecosystem is the least concerned with a marine ecosystem which subjects this region to the massive ecosystem degradation from urban expansion.

Thus ES\&ED studies with focus on urbanisation aspect are highly recommended as well as ecosystem service trade-offs analysis. English as language barriers in publication, the publisher would discuss this matter specifically in West Africa context to accommodate publications in French in which the authors are 
purely French.

\section{Acknowledgements}

This study is part of a Ph.D. project funded by Africa Union Commission research Grant through Pan-African University. We sincerely thank Dr. Jones, Laurence from the Centre of Ecology and Hydrology, Edinburgh, UK for his inspiration to start this review paper.

\section{Conflicts of Interest}

The authors declare no conflict of interest. The founding sponsor had no role in the design of the study; in the collection, analyses, or interpretation of data; in the writing of the manuscript; or in the decision to publish the results.

\section{References}

[1] Dale, A., Ustan, T.S., Tan, D., Waltham, N., Laurance, W.F., Rojas, C., Diew, Y.W., Ziembicki, M., Penny, A., Kuah, A.T., Hussain, S., McJannet, K., Langston, J., Riggs, R., Sharif, D.M.M., Rohaida, S. and Jamaludin, S.R. (2017) State of the Tropics: Sustainable Infrastructure for the Tropics. James Cook University Townsville, Townsville, Australia.

[2] Alexandra Edelman. Gedling, A., Konovalov, E., McComiskie, R., Penny, A., Roberts, N., Templeman, S., Trewin, D. and Ziembicki, M. (2014) The State of the Tropics. James Cook University and the State of the Tropics leadership Group, Australia.

[3] Gullison, R.E., Frumhoff, P.C., Canadell, J.G., Field, C.B., Nepstad, D.C., Hayhoe, K., Avissar, R., Curran, L.M., Friedlingstein, P., Jones, C.D. and Nobre, C. (2007) Tropical Forests and Climate Policy. Science, 316, 985-986. https://doi.org/10.1126/science.1136163

[4] Lamb, D., Erskine, P.D. and Parrotta, J.A. (2005) Restoration of Degraded Tropical Forest Landscapes. Science, 310, 1628-1632.

https://doi.org/10.1126/science.1111773

[5] Romañach, S.S., De Angelis, D.L., Koh, H.L., Li, Y., Teh, S.Y., Raja Barizan, R.S. and Zhai, L. (2018) Conservation and Restoration of Mangroves: Global Status, Perspectives, and Prognosis. Ocean \& Coastal Management, 154, 72-82. https://doi.org/10.1016/j.ocecoaman.2018.01.009

[6] Keenan, R.J., Reams, G.A., Achard, F., de Freitas, J.V., Grainger, A. and Lindquist, E. (2015) Dynamics of Global Forest Area: Results from the FAO Global Forest Resources Assessment 2015. Forest Ecology and Management, 352, 9-20. https://doi.org/10.1016/j.foreco.2015.06.014

[7] UN (2017) World Economic Situation and Prospects. New York, USA.

[8] Malinga, R., Gordon, L.J., Jewitt, G. and Lindborg, R. (2015) Mapping Ecosystem Services across Scales and Continents: A Review. Ecosystem Services, 13, 57-63. https://doi.org/10.1016/j.ecoser.2015.01.006

[9] Ehrlich, P.R. and Mooney, H.A. (1983) Extinction, Substitution, Ecosystem Services. Bioscience, 33, 248-254. https://doi.org/10.2307/1309037

[10] Gómez-Baggethun, E., Groot, R., De. Lomas, P.L. and Montes, C. (2010) The History of Ecosystem Services in Economic Theory and Practice: From Early Notions to Markets and Payment Schemes. Ecological Economics, 69, 1209-1218. 
https://doi.org/10.1016/j.ecolecon.2009.11.007

[11] Costanza, R., D’Arge, R., de Groot, R., Farber, S., Grasso, M., Hannon, B., Limburg, K., Naeem, S., O’Neill, R.V., Paruelo, J., Raskin, R.G., Sutton, P. and van den Belt, M. (1998) The Value of Ecosystem Services: Putting the Issues in Perspectives. Ecological Economics, 25, 67-72. https://doi.org/10.1016/S0921-8009(98)00019-6

[12] Costanza, R. (1997) The Value of the World's Ecosystem Services and Natural Capital. Nature, 387, 253-260. https://doi.org/10.1038/387253a0

[13] Romero, H.G. (2012) Payments for Environmental Services: Can They Work? The Case of Mexico. Field Actions Science Reports, No. 6, 1-6.

[14] Wangai, P.W., Burkhard, B. and Muller, F. (2016) A Review of Studies on Ecosystem Services in Africa. International Journal of Environmental Sustainability, 5, 225-245. https://doi.org/10.1016/j.ijsbe.2016.08.005

[15] Klein, L.F., Eisenstein, J. and Sun, I. (2015) Exploratory Thematic Analysis for Digitized Archival Collections. Digital Scholarship in the Humanities, 30, i130-i141. https://doi.org/10.1093/llc/fqv052

[16] Eisenstein, J., Sun, I. and Klein, L. (2014) Exploratory Thematic Analysis for Historical Newspaper Archives. Digital Humanities, 154-155.

[17] Mcllroy, T. (2013) Exploring Poetry and Identity in a Language Learning Environment. Studies in Linguistics and Language Teaching, 24, 31-45.

[18] Harrison, P.A., Dunford, R., Barton, D.N., Kelemen, E., Martín-López, B., Norton, L., Termansen, M., Saarikoski, H., Hendriks, K., Gómez-Baggethun, E., Czúcz, B., García-Llorente, M., Howard, D., Jacobs, S., Karlsen, M., Kopperoinen, L., Madsen, A., Rusch, G., van Eupen, M., Verweij, P., Smith, R., Tuomasjukka, D. and Zulian, G. (2017) Selecting Methods for Ecosystem Service Assessment: A Decision Tree Approach. Ecosystem Services, 29, 481-498. https://doi.org/10.1016/j.ecoser.2017.09.016

[19] Bagstad, K.J., Semmens, D.J., Waage, S. and Winthrop, R. (2013) A Comparative Assessment of Decision-Support Tools for Ecosystem Services Quantification and Valuation. Ecosystem Services, 5, 27-39. https://doi.org/10.1016/j.ecoser.2013.07.004

[20] Dunford, R., Harrison, P., Smith, A., Dick, J., Barton, D.N., Martin-Lopez, B., Kelemen, E., Jacobs, S., Saarikoski, H., Turkelboom, F., Verheyden, W., Hauck, J., Antunes, P., Aszalós, R., Badea, O., Baró, F., Berry, P., Carvalho, L., Conte, G., Czúcz, B., Garcia Blanco, G., Howard, D., Giuca, R., Gomez-Baggethun, E., Grizetti, B., Izakovicova, Z., Kopperoinen, L., Langemeyer, J., Luque, S., Lapola, D.M., Martinez-Pastur, G., Mukhopadhyay, R., Roy, S.B., Niemelä, J., Norton, L., Ochieng, J., Odee, D., Palomo, I., Pinho, P., Priess, J., Rusch, G., Saarela, S.R., Santos, R., van der Wal, J.T., Vadineanu, A., Vári, Á., Woods, H. and Yli-Pelkonen, V. (2018) Integrating Methods for Ecosystem Service Assessment: Experiences from Real World Situations. Ecosystem Services, 29, 499-514.

https://doi.org/10.1016/j.ecoser.2017.10.014

[21] Hattam, C., Böhnke-Henrichs, A., Börger, T., Burdon, D., Hadjimichael, M., Delaney, A., Atkins, J.P., Garrard, S. and Austen, M.C. (2015) Integrating Methods for Ecosystem Service Assessment and Valuation: Mixed Methods or Mixed Messages? Ecological Economics, 120, 126-138. https://doi.org/10.1016/j.ecolecon.2015.10.011

[22] Chinangwa, L., Gasparatos, A. and Saito, O. (2017) Forest Conservation and the Private Sector: Stakeholder Perceptions towards Payment for Ecosystem Service Schemes in the Tobacco and Sugarcane Sectors in Malawi. Sustainability Science, 
12, 727-746. https://doi.org/10.1007/s11625-017-0469-6

[23] Boon, E. (2013) Assessing Climate Change Impacts on Ecosystem Services and Livelihoods in Ghana: Case Study of Communities around Sui Forest Reserve. Journal of Ecosystem and Ecography, 3, 001. https://doi.org/10.4172/2157-7625.S3-001

[24] Ngom, D., Charahabil, M.M., Sarr, O., Bakhoum, A. and Akpo, L.E. (2014) Perceptions communautaires sur les services écosystémiques d ' approvisionnement fournis par le peuplement ligneux de la Réserve de Biosphère du Ferlo (Sénégal). VertigO, 14, 1-18. https://doi.org/10.4000/vertigo.15188

[25] Schumann, K. and Hahn, K. (2015) Stratégies d' adaptation à la réduction des services écosystémiques: Cas des potentialités de substitution de trois espèces forestières dans le Sud-Ouest du Burkina Faso. International Journal of Biological Sciences, 9, 1194-1208. https://doi.org/10.4314/ijbcs.v9i3.5

[26] Kotoudéni Bene, A. and Fournier, A. (2015) Réflexion sur la notion de services écologiques: Étude de cas à Kotoudéni (Burkina Faso). VertigO, 15, 1-18.

[27] Rouillé, G., Blanchon, D., Calas, B. and Temple-Boyer, É. (2015) Environnement, écologisation du politique et territorialisations: Les nouvelles politiques de l' eau (gire et pse) au Kenya. L'Espace géographique, 2, 131-146. https://doi.org/10.3917/eg.442.0131

[28] Dieng, S.D., Diop, M., Goudiaby, A., Niang-diop, F., Faye, C., Guiro, I., Sambou, S., Lykke, A.M. and Sambou, B. (2016) Caractérisation des services écosystémiques fournis par Cordyla pinnata dans la périphérie de la Forêt classée de Patako au Sénégal. VertigO, 16, 1-18. https://doi.org/10.4000/vertigo.17634

[29] Nhecolandia, P., Seidl, A.F. and Steffens, A. (2000) Global Valuation of Ecosystem Services: Application to the Pantanal da Nhecolandia, Brazil. Ecological Economics, 33, 1-6. https://doi.org/10.1016/S0921-8009(99)00146-9

[30] Kaplowitz, M.D. (2000) Identifying Ecosystem Services Using Multiple Methods: Lessons from the Mangrove Wetlands of Yucatan, Mexico. Agriculture and Human Values, 17, 169-179. https://doi.org/10.1023/A:1007669404425

[31] Herrador, D. and Dimas, L. (2000) Payment for Environmental Services in El Salvador. Mountain Research and Development, 20, 306-309. https://doi.org/10.1659/0276-4741(2000)020[0306:PFESIE]2.0.CO;2

[32] Salih, S.A. (1992) Managing Renewable Natural capital in Africa. Helsinki, 97.

[33] Shepande, C. (2002) Soils and Land Use with Particular Attention to Land Evaluation for Selected Land Use Types in the Lake Naivasha Basin, Kenya, ITC, Netherlands.

[34] Williams-guillen, K. and Otterstrom, S. (2014) Market-Based Incentives for the Conservation of Ecosystem Services in Agricultural Landscapes: Examples from Coffee Cultivation in Latin America. Encyclopedia of Agriculture and Food Systems, 4, 172-185. https://doi.org/10.1016/B978-0-444-52512-3.00011-5

[35] Dhanya, B., Sathish, B.N., Viswanath, S. and Purushothaman, S. (2014) Ecosystem Services of Native Trees: Experiences from Two Traditional Agroforestry Systems in Karnataka, Southern India. International Journal of Biodiversity Science, Ecosystem Services \& Management, 10, 101-111. https://doi.org/10.1080/21513732.2014.918057

[36] Purnamasari, U. (2015) Mountain Ecosystem Assessment Based on Ecosystem Services and Human Activities: A Case in Upper Part of Bogowonto Watershed, Indonesia. The SIJ Transactions on Advances in Space Research \& Earth Exploration, 3, 
8-13.

[37] Caballero-serrano, V., Onaindia, M., Alday, J.G., Caballero, D., Carlos, J., Mclaren, B. and Amigo, J. (2016) Agriculture, Ecosystems and Environment Plant Diversity and Ecosystem Services in Amazonian Homegardens of Ecuador. Agriculture, Ecosystems \& Environment, 225, 116-125. https://doi.org/10.1016/j.agee.2016.04.005

[38] Adams, H., Adger, W.N., Ahmad, S., Ahmed, A., Begum, D., Lázár, A.N., Matthews, Z., Rahman, M.M. and Streatfield, P.K. (2016) Data Descriptor: Spatial and Temporal Dynamics of Multidimensional Well-Being, Livelihoods and Ecosystem Services in Coastal Bangladesh. Scientific Data, 3, 1-11.

https://doi.org/10.1038/sdata.2016.94

[39] Le Coq, J.F., Froger, G., Pesche, D., Legrand, T. and Saenz, F. (2015) Understanding the Governance of the Payment for Environmental Services Programme in Costa Rica: A Policy Process Perspective. Ecosystem Services, 16, 253-265. https://doi.org/10.1016/j.ecoser.2015.10.003

[40] Souza, J.R. De. Santos, R.C., Silva, I.R., Elliff, C.I., Filho, J.R.D.S., Santos, R.C., Silva, I.R. and Elliff, C.I. (2014) Evaluation of Recreational Quality, Carrying Capacity and Ecosystem Services Supplied by Sandy Beaches of the Municipality of Camaçari, Northern Coast Bahia, Brazil. Journal of Coastal Research, 70, 527-532. https://doi.org/10.2112/SI70-089.1

[41] Montoya-Tangarife, C., De La Barrera, F., Salazar, A. and Inostroza, L. (2017) Monitoring the Effects of Land Cover Change on the Supply of Ecosystem Services in an Urban Region: A study of Santiago-Valparaíso, Chile. PLoS ONE, 12, e0188117. https://doi.org/10.1371/journal.pone.0188117

[42] Martin, C.L., Momtaz, S., Gaston, T. and Moltschaniwskyj, N.A. (2016) A Systematic Quantitative Review of Coastal and Marine Cultural Ecosystem Services: Current Status and Future Research. Marine Policy, 74, 25-32. https://doi.org/10.1016/j.marpol.2016.09.004

[43] Mahajan, S.L. and Daw, T. (2016) Perceptions of Ecosystem Services and Benefits to Human Well-Being from Community-Based Marine Protected Areas in Kenya. Marine Policy, 74, 108-119. https://doi.org/10.1016/j.marpol.2016.09.005

[44] Awuor, M., Icely, J., Newton, A., Nyunja, J., Otieno, P., Omondi, A. and Oduor, N. (2017) Mapping of Ecosystem Services Flow in Mida Creek, Kenya. Ocean \& Coastal Management, 140, 11-21. https://doi.org/10.1016/j.ocecoaman.2017.02.013

[45] Abunge, C., Coulthard, S. and Daw, T.M. (2013) Connecting Marine Ecosystem Services to Human Well-Being: Insights from Participatory Well-Being Assessment in Kenya. AMBIO, 42, 1010-1021. https://doi.org/10.1007/s13280-013-0456-9

[46] Faillera, P., Pètrea, É., Bineta, T. and Maréchalb, J.-P. (2015) Valuation of Marine and Coastal Ecosystem Services as a Tool for Conservation: The Case of Martinique in the Caribbean. Ecosystem Services, 11, 67-75. https://doi.org/10.1016/j.ecoser.2014.10.011

[47] Binet, T., Failler, P., Chavance, P.N. and Mayif, M.A. (2013) First International Payment for Marine Ecosystem Services: The Case of the Banc d'Arguin National Park, Mauritania. Global Environmental Change, 23, 1434-1443. https://doi.org/10.1016/j.gloenvcha.2013.09.015

[48] La, A., Amato, D.D., Mäkinen, H., Luisa, M., Liquete, C., Egoh, B., Geneletti, D. and Crossman, N.D. (2017) Ecosystem Services Classification: A Systems Ecology Perspective of the Cascade Framework. Ecological Indicators, 74, 392-402. https://doi.org/10.1016/j.ecolind.2016.11.030

[49] MA Ecosystems and Human WELL-BEING: Synthesis (2005) Island Press, Wash- 
ington, USA.

[50] Díaz, S., Demissew, S., Carabias, J., Joly, C., Lonsdale, M. and Al., E. (2015) The IPBES Conceptual Framework: Connecting Nature and People. Current Opinion in Environmental Sustainability, 14, 1-16. https://doi.org/10.1016/j.cosust.2014.11.002

[51] Birk, A., Biala, K., Christiansen, T. and Werner, B. (2018) Mapping and Assessment of Ecosystems and Their Services: An Analytical Framework for Ecosystem Assessments under Action 5 of the EU Biodiversity Strategy to 2020. European Union (EU), Luxembourg, Belgium.

[52] UNEP (2008) TEEB The Economics of Ecosystems \& Biodiversity. Cambridge, UK.

[53] Lyytimäki, J., Petersen, L.K., Normander, B. and Bezák, P. (2008) Nature as a Nuisance? Ecosystem Services and Disservices to Urban Lifestyle. Environmental Science, 5, 161-172. https://doi.org/10.1080/15693430802055524

[54] Lithgow, D., Martínez, M.L., Silva, R., Geneletti, D., Gallego-, J.B., Cerdán, C.R., Mendoza, E. and Jermain, A. (2017) Ecosystem Services to Enhance Coastal Resilience in Mexico: The Gap between the Perceptions of Decision-Makers and Academics. Journal of Coastal Research, 77, 116-126. https://doi.org/10.2112/SI77-012.1

[55] Sarukhan, J. and Jimenez, R. (2016) Generating Intelligence for Decision Making and Sustainable Use of Natural Capital in Mexico. Current Opinion in Environmental Sustainability, 19, 153-159. https://doi.org/10.1016/j.cosust.2016.02.002

[56] Russo, T. and Candela, T.G. (2006) Payment of Environmental Services in Costa Rica: Evaluating Impact and Possibilities. Tierra Tropical, 2, 37-48.

[57] Cozzolino, G. and Piazzi, A. (2017) How to Finance Biodiversity Conservation Policies in a Developing Country through Ecosystem Services: The Case of Mozambique. Natural Resources and Conservation, 5, 56-64.

[58] Mhango, J., Dick, J., Mhango, J. and Dick, J. (2011) Analysis of Fertilizer Subsidy Programs and Ecosystem Services in Malawi. Renewable Agriculture and Food Systems, 26, 200-207. https://doi.org/10.1017/S1742170510000517

[59] Zaehringer, J.G., Schwilch, G., Andriamihaja, O.R., Ramamonjisoa, B. and Messerli, P. (2017) Remote Sensing Combined with Social-Ecological Data: The Importance of Diverse Land Uses for Ecosystem Service Provision in North-Eastern Madagascar. Ecosystem Services, 25, 140-152. https://doi.org/10.1016/j.ecoser.2017.04.004

[60] Abebe, S., Hurni, H. and Zeleke, G. (2013) Long-Term Changes in Soil-Based Ecological Services at Three Sites in Ethiopia. Journal of Ecology and the Natural Environment, 5, 172-180. https://doi.org/10.5897/JENE2013.0392

[61] Ango, T.G., Börjeson, L., Senbeta, F. and Hylander, K. (2014) Balancing Ecosystem Services and Disservices: Smallholder Farmers' Use and Management of Forest and Trees in an Agricultural Landscape in Southwestern Ethiopia. Ecology and Society, 19, 1-16. https://doi.org/10.5751/ES-06279-190130

[62] Dorresteijn, I., Schultner, J., French, N., Kristoffer, C., Senbeta, F. and Fischer, J. (2017) Disaggregating Ecosystem Services and Disservices in the Cultural Landscapes of Southwestern Ethiopia: A Study of Rural Perceptions. Landscape Ecology, 32, 2151-2165. https://doi.org/10.1007/s10980-017-0552-5

[63] Shackleton, S.E. and Shackleton, R.T. (2017) Local Knowledge Regarding Ecosystem Services and Disservices from Invasive Alien Plants in the Arid Kalahari, South Africa. Journal of Arid Environments, 159, 22-33.

https://doi.org/10.1016/j.jaridenv.2017.07.001 
[64] Ninan, K.N. and Kontoleon, A. (2016) Valuing Forest Ecosystem Services and Disservices: Case Study of a Protected Area in India. Ecosystem Services, 10, 1-14. https://doi.org/10.1016/j.ecoser.2016.05.001

[65] García-Amado, L.R., Pérez, M.R., Escutia, F.R., García, S.B. and Mejía, E.C. (2011) Efficiency of Payments for Environmental Services: Equity and Additionality in a Case Study from a Biosphere Reserve in Chiapas, Mexico. Ecological Economics, 70, 2361-2368. https://doi.org/10.1016/j.ecolecon.2011.07.016

[66] Fisher, B., Kulindwa, K., Mwanyoka, I., Turner, R.K. and Burgess, N.D. (2010) Common Pool Resource Management and PES: Lessons and Constraints for Water PES in Tanzania. Ecological Economics, 69, 1253-1261. https://doi.org/10.1016/j.ecolecon.2009.11.008

[67] Kumar, P. (2011) Capacity Constraints in Operation Alisation of Payment for Ecosystem Services (PES) in India: Evidence from Land Degradation. Land Degradation \& Development, 443, 432-443. https://doi.org/10.1002/ldr.1024

[68] Ajwang, R., Kitaka, N. and Oduor, S.O. (2016) Assessment of Provisioning and Cultural Ecosystem Services in Natural Wetlands and Rice Fields in Kano Floodplain, Kenya. Ecosystem Services, 21, 166-173. https://doi.org/10.1016/j.ecoser.2016.08.008

[69] Thompson, B.S., Primavera, J.H. and Friess, D.A. (2017) Governance and Implementation Challenges for Mangrove Forest Payments for Ecosystem Services (PES): Empirical Evidence from the Philippines. Ecosystem Services, 23, 146-155. https://doi.org/10.1016/j.ecoser.2016.12.007

[70] Environments, A., Eshete, G. and Redd, R. (2013) Wood Biomass Functions for Acacia Abyssinica Trees and Shrubs and Implications for Provision of Ecosystem Services in a Community Managed Exclosure in Tigray, Ethiopia K. Journal of Arid Environments, 94, 80-86. https://doi.org/10.1016/j.jaridenv.2013.03.001

[71] Abdar, M.R. (2014) Seasonal Diversity of Birds and Ecosystem Services in Agricultural Area of Western Ghats, Maharashtra State, India. IOSR Journal of Environmental Science, Toxicology and Food Technology, 8, 100-105. https://doi.org/10.9790/2402-0811100105

[72] Jujnovsky, J., Almeida-Leñero, L., Bojorge-García, M., Monges, Y.L., Cantoral-Uriza, E. and Mazari-Hiriart, M. (2010) Hydrologic Ecosystem Services: Water Quality and Quantity in the Magdalena River, Mexico City. Hidrobiológica, 20, 113-126.

[73] Bak, Y.L., Said, I., Saito, K., Ling, G. and Teck, H. (2016) Conceptual Framework of Ecosystem Services in Landscape Planning, Malaysia. International Journal of Environmental Sustainability, 3, 142-149. https://doi.org/10.11113/ijbes.v3.n3.137

[74] Garcia, G., Antônio, L., Freitas, D., Oliveira, G., Ximenes, C., Macedo, D. and Casarin, D. (2015) The Challenges of Implementing a Legal Framework for Payment for Ecosystem Services in Santa Catarina, Brazil. Nature Conservation, 14, 132-136. https://doi.org/10.1016/j.ncon.2016.05.003

[75] Atwell, M.A. (2017) Sustainable Management of Tropical Small Island Ecosystems for the Optimization of Soil Natural Capital and Ecosystem Services: A Case of a Caribbean Soil Ecosystem-Aripo Savannas Trinidad. Journal of Soils and Sediments, 18, 1-14. https://doi.org/10.1007/s11368-017-1865-3

[76] Herrador, D. and Dimas, L. (2000) Payment for Environmental Services in El Salvador. Mountain Research and Development, 20, 306-309. https://doi.org/10.1659/0276-4741(2000)020[0306:PFESIE]2.0.CO;2

[77] Boyer, C. and Carino, M. (2013) Mexico's Environmental Revolutions. In: Claudia, 
L., Pádua, J.A. and Solur, J., Eds., New Environmental Histories of Latin America and the Caribbean, RCC Perspectives, Munich, 9-15.

[78] Díez, J. (2008) The Rise and Fall of Mexico’s Green Movement. Revista Europea de Estudios Latinoamericanos y del Caribe, 85, 81-99. https://doi.org/10.18352/erlacs.9620

[79] Obi, C.I. (2005) Environmental Movements in Sub-Saharan Africa: A Political Ecology of Power and Conflict. Geneva.

[80] Death, C. (2014) Environmental Movements, Climate Change, and Consumption in South Africa. Journal of Southern African Studies, 40, 1215-1234. https://doi.org/10.1080/03057070.2014.964494

[81] Cock, J. (2004) Connecting the Red, Brown and Green: The Environmental Justice Movement in South Africa. Durban, South Africa.

[82] Abiolu, O.A. and Okere, O.O. (2012) Environmental Literacy and the Emerging Roles of Information Professionals in Developing Economies. IFLA Journal, 38, 53-59. https://doi.org/10.1177/0340035211435070

[83] Haase, D., Larondelle, N., Andersson, E., Artmann, M., Gomez-baggethun, E., Hansen, R., Kabisch, N., Kremer, P., Langemeyer, J., Rall, E.L., Mcphearson, T., Pauleit, S., Qureshi, S., Schwarz, N., Voigt, A., Wurster, D. and Elmqvist, T. (2014) A Quantitative Review of Urban Ecosystem Service Assessments: Concepts, Models, and Implementation. AMBIO: A Journal of the Human Environment, 43, 413-433. https://doi.org/10.1007/s13280-014-0504-0

[84] Okere, O.A.A.O.O. (2011) Environmental Literacy and the Emerging Roles of Information Professionals in Developing Economies. Sustainable Innovation and Green Information for All, Puerto Rico, 1-11.

[85] FAO Cadre de programmation du pays 2013-2017. DRC, KInshasa.

[86] Altbach, P.G. (2007) The Imperial Tongue: English as the Dominating Academic Language. Economic and Political Weekly, 42, 3608-3611.

[87] Hashim, A. and Low, E.-L. (2014) Introduction: English in Southeast Asia. World Englishes, 33, 423-425. https://doi.org/10.1111/weng.12104

[88] Goldstein, J.H., Caldarone, G., Duarte, T.K., Ennaanay, D., Hannahs, N., Mendoza, G., Polasky, S., Wolny, S. and Daily, G.C. (2012) Integrating Ecosystem-Service Tradeoffs into Land-Use Decisions. Proceedings of the National Academy of Sciences of the United States of America, 109, 7565-7570.

https://doi.org/10.1073/pnas.1201040109

[89] Rodríguez, J.P., Beard, T.D., Bennett, E.M., Cumming, G.S., Cork, S.J., Agard, J., Dobson, A.P. and Peterson, G.D. (2006) Trade-Offs across Space, Time, and Ecosystem Services. Ecology and Society, 11, 28.

[90] Crossman, N.D., Burkhard, B., Nedkov, S., Willemen, L., Petz, K., Palomo, I., Drakou, E.G., Martı, B., Mcphearson, T., Boyanova, K., Alkemade, R., Egoh, B., Dunbar, M.B. and Maes, J. (2013) A Blueprint for Mapping and Modelling Ecosystem Services. Ecosystem Services, 4, 4-14. https://doi.org/10.1016/j.ecoser.2013.02.001

[91] Burkhard, B. and Kiel, C. (2014) Ecosystem Service Potentials, Flows and Demands-Concepts for Spatial Localisation, Indication and Quantification. Landscape Online, 34, 1-32. https://doi.org/10.3097/LO.201434

[92] TekleWoldegerima. Yeshitela, K. and Lindley, S. (2017) Ecosystem Services Assessment of the Urban Forests of Addis, Ethiopia. Urban Ecosystems, 20, 683-699. https://doi.org/10.1007/s11252-016-0624-3

[93] Lupala, J.M., Mdemu, M.V. and Butungo, S.P. (2014) Effects of Peri-Urban Land 
Use Changes on Forest Ecosystem Services: The Case of Settlements Surrounding Pugu and Kazimzumbwi Forest Reserves in Tanzania. Journal of Geography and Geology, 6, 231-240. https://doi.org/10.5539/jgg.v6n4p231

[94] Ifatimehin, O., Oluseyi, P. and Olu, T. (2014) Ecosystem Regulatory Services and Human Comfort in an Outdoor Environment of Lokoja, Nigeria. British Journal of Applied Physics, 18, 2576-2589. https://doi.org/10.9734/BJAST/2014/6515

[95] Intralawan, A. and Rueangkitwat, I. (2016) Ecosystem Services Tradeoffs: A Case Study of Chiang Khong, Thailand. Environment Asia, 9, 64-71.

[96] Bruno, L., Pablo, I. and Wunder, S. (2013) Synergies and Trade-Offs between Ecosystem Services in Costa Rica. Environmental Conservation, 41, 27-36. https://doi.org/10.1017/S0376892913000234

[97] Grêt-Regamey, A., Celio, E., Klein, T.M. and Hayek, U.W. (2013) Landscape and Urban Planning Understanding Ecosystem Services Trade-Offs with Interactive Procedural Modeling for Sustainable Urban Planning. Landscape and Urban Planning, 109, 107-116. https://doi.org/10.1016/j.landurbplan.2012.10.011

[98] Von Döhren, P. and Haase, D. (2015) Ecosystem Disservices Research: A Review of the State of the Art with a Focus on Cities. Ecological Indicators, 52, 490-497. https://doi.org/10.1016/j.ecolind.2014.12.027

[99] Portman, M.E. (2013) Ecosystem Services in Practice: Challenges to Real World implementation of Ecosystem Services across Multiple Landscapes: A Critical Review. Applied Geography, 45, 185-192. https://doi.org/10.1016/j.apgeog.2013.09.011

[100] UN-HABITAT Issue Paper on Smart Cities: 21 Smart Cities (2015) New York, USA.

[101] Elmqvist, T., Fragkias, M., Goodness, J., Güneralp, B., Marcotullio, P.J., McDonald, R.I., Parnell, S., Schewenius, M., Sendstad, M., Seto, K.C. and Wilkinson, C. (2013) Urbainzation, Biodiversity and Ecosystem Services: Challenges and Opportunities. A Global Assessment. Springer, Berlin. https://doi.org/10.1007/978-94-007-7088-1

[102] Haregeweyn, N., Fikadu, G., Tsunekawa, A., Tsubo, M. and Meshesha, D.T. (2012) The Dynamics of Urban Expansion and Its Impacts on Land Use/Land Cover Change and Small-Scale Farmers Living Near the Urban Fringe: A Case Study of Bahir Dar, Ethiopia. Landscape and Urban Planning, 106, 149-157. https://doi.org/10.1016/j.landurbplan.2012.02.016

[103] Buhaug, H. and Urdal, H. (2013) An Urbanization Bomb ? Population Growth and Social Disorder in Cities. Global Environmental Change, 23, 1-10. https://doi.org/10.1016/j.gloenvcha.2012.10.016

[104] Dunn, R.R. (2010) Global Mapping of Ecosystem Disservices: The Unspoken Reality That Nature Sometimes Kills Us. Biotropica, 42, 555-557. https://doi.org/10.1111/j.1744-7429.2010.00698.x

[105] Dobbs, C., Escobedo, F.J. and Zipperer, W.C. (2011) A Framework for Developing Urban Forest Ecosystem Services and Goods Indicators. Landscape and Urban Planning, 99, 196-206. https://doi.org/10.1016/j.landurbplan.2010.11.004

[106] Shackleton, C.M., Ruwanza, S., Sinasson Sanni, G.K., Bennett, S., De Lacy, P., Modipa, R., Mtati, N., Sachikonye, M. and Thondhlana, G. (2016) Unpacking Pandora's Box: Understanding and Categorising Ecosystem Disservices for Environmental Management and Human Wellbeing. Ecosystems, 19, 587-600. https://doi.org/10.1007/s10021-015-9952-Z

[107] Vaz, A.S., Kueffer, C., Kull, C.A., Richardson, D.M., Vicente, J.R., Kühn, I., Schröter, M., Hauck, J., Bonn, A. and Honrado, J.P. (2017) Integrating Ecosystem Services and Disservices: Insights from Plant Invasions. Ecosystem Services, 23, 94-107. https://doi.org/10.1016/j.ecoser.2016.11.017 